Volume 3, No. 2 Januari 2020

\title{
PENERAPAN SUPERVISI AKADEMIK SEBAGAI UPAYA PENINGKATAN KOMPETENSI GURU DALAM MENGEMBANGKAN INOVASI PEMBELAJARAN MELALUI KEGIATAN TEAM TEACHING DI SLBAKW KUMARA SURABAYA TAHUN 2018
}

\author{
Drs. R. MUJIRAHARJO, M.M
}

Dinas Pendidikan Provinsi Jawa Timur

\begin{abstract}
Abstrak
Tujuan dari penelitian ini adalah untuk mendeskripsikan penerapan Supervisi Akademik sebagai upaya peningkatan kompetensi guru dalam mengembangkan inovasi pembelajaran melalui kegiatan Team Teaching di SLB AKW Kumara Surabaya Tahun 2018. Subyek dalam Penelitian Tindakan Sekolah ini adalah guru-guru yang berasal dari SLB AKW Kumara Surabaya yang tergabung dalam kegiatan Team Teaching yang berjumlah 30 orang. Kegiatan ini bertempat di SLB AKW Kumara, yang terletak di Jl. Medokan Semampir Indah 95, Surabaya. Waktu dalam penelitian ini adalah 02 sampai 30 Oktober 2018. Penelitian ini dilakukan dalam dua siklus dan masing-masing siklus terdiri atas: perencanaan, pelaksanaan, observasi dan refleksi. Hasil penelitian ini yaitu peningkatan kompetensi guru dalam mengembangkan inovasi pembelajaran melalui Team Teaching. Hal itu terbukti bahwa siklus I ke siklus II, kategori baik dan sangat baik pada aspek Inovasi Perencanaan Pembelajaran meningkat dari 66,67\% menjadi 96,67\%. Pada aspek Inovasi Materi Pembelajaran meningkat dari 70,00\% menjadi 93,33\%. Pada aspek Inovasi Metode Pembelajaran meningkat dari 70,00\% menjadi 90,00\%. Pada aspek Inovasi Media Pembelajaran meningkat dari 76,67\% menjadi 96,67\%. Pada aspek Inovasi Evaluasi Pembelajaran meningkat dari 70,00\% menjadi 96,67\%.
\end{abstract}

Kata Kunci: Supervisi Akademik, Kompetensi Guru, Inovasi Pembelajaran, Kegiatan Team Teaching

\section{PENDAHULUAN}

Proses pembelajaran merupakan inti dari kegiatan pendidikan di sekolah. Guru merupakan personel yang menduduki posisi metodes dalam rangka pengembangan sumber daya manusia, dituntut untuk terus mengikuti berkembangan konsepkonsep baru dalam dunia pembelajaran.

Menurut James B. Brow seperti yang dikutip oleh Sardiman mengemukakan bahwa tugas dan peranan guru antara lain: menguasai dan mengembangkan materi pelajaran, merencanakan dan mempersiapkan pelajaran sehari-hari, mengontrol dan mengevaluasi kegiatan siswa. Tugas guru dalam proses pembelajaran meliputi tugas paedagogis dan tugas administrasi. Tugas paedagogis adalah tugas membantu, membimbing dan memimpin. Moh. Rifai mengatakan bahwa, di dalam situasi pembelajaran, gurulah yang memimpin dan bertanggung jawab penuh atas kepemimpinannya yang dilakukan itu. Ia tidak melakukan instruksi-instruksi dan tidak berdiri di bawah instruksi manusia lain kecuali dirinya sendiri, setelah masuk dalam situasi kelas (dalam Suryasubroto, 1997, hlm. 4).

Disinilah guru sebagai pendidik memiliki peran yang sangat besar, disamping sebagai fasilitator dalam pembelajaran siswa, juga sebagai pembimbing dan mengarahkan peserta didiknya sehingga menjadi manusia yang mempunyai pengetahuan luas baik pengetahuan agama, kecerdasan, kecakapan hidup, 
keterampilan, budi pekerti luhur dan kepribadian baik dan bisa membangun dirinya untuk lebih baik dari sebelumnya serta memiliki tanggung jawab besar dalam pembangunan bangsa.

Oleh karena itu, guru harus mengetahui bagaimana situasi dan kondisi ajaran itu disampaikan kepada peserta didik, saran apa saja yang diperlukan untuk mencapai keberhasilan belajar, bagaimana cara atau pendekatan yang digunakan dalam penbelajaran, bagaimana mengorganisasikan dan mengelola isi pembelajaran, hasil yang diharapkan dari kegiatan tersebut, dan seberapa jauh tingkat efektifitas, efisiennya serta usaha-usaha apa yang dilakukan untuk menimbulkan daya tarik bagi peserta didik.

Dalam kegiatan

pembelajaran terdapat dua kegiatan yang sinergik, yakni guru mengajar dan siswa belajar. Guru mengajarkan bagaimana siswa harus belajar. Sementara siswa belajar bagaimana seharusnya belajar melalui berbagai pengalaman belajar hingga terjadi perubahan dalam dirinya dari aspek kognitif, psikomotorik, dan afektif. Guru yang kompeten akan lebih mampu menciptakan lingkungan yang efektif dan akan lebih mampu mengelola proses pembelajaran, sehingga hasil belajar siswa berada pada tingkat yang optimal.

Belajar memang bukan konsekuensi otomatis dari penyampaian informasi pada anak didik, tapi belajar membutuhkan keterlibatan mental dan tindakan dari pelajar itu sendiri. Itulah keaktifan yang merupakan langkah-langkah belajar yang didesain agar siswa senang mendukung proses itu dan menarik minat untuk terlibat.

Mengaktifkan belajar siswa
kegiatan pembelajaran
merupakan salah satu cara
menghidupkan dan melatih memori
siswa agar bekerja dan berkembang
secara optimal. Guru harus memberi
kesempatan kepada siswa untuk
mengoptimalkan memorinya bekerja
secara maksimal dengan bahasanya
dan melakukan dengan kreatifitasnya
sendiri.

Dalam pembelajaran terdapat beberapa komponen yang berpengaruh dalam proses pembelajaran, yang salah satunya adalah inovasi pembelajaran. Apabila ditinjau dari karakteristik setiap individu dari anak didik pasti memiliki perbedaan dalam hal kemampuan siap, gaya belajar, perkembangan moral, perkembangan kepercayaan, perkembangan kognitif, social budaya dan sebagainya. Untuk itu guru harus mampu menjadikan mereka semua terlibat, merasa senang selama proses pembelajaran.

Inovasi pembelajaran merupakan salah satu cara yang dipergunakan guru dalam mengadakan hubungan siswa pada saat berlangsungnya pembelajaran. Oleh karena itu, peranan metode mengajar sebagai alat untuk menciptakan proses pembelajaran (Suryasubroto, 1997, hlm. 43).

Dengan metode yang tepat seseorang dapat meraih prestasi belajar secara berlipat ganda. Hal itu tentu saja merupakan peluang dan tantangan yang menggembirakan bagi 
kalangan pendidik. Tetapi jika bangsa Indonesia terlambat mengapresiasikan berbagai temuan mutakhir dalam bidang metodologi pendidikan, maka posisi kita akan semakin tertinggal di belakang. Inovasi pembelajaran yang tepat dan dapat memberikan motivasi belajar yang tinggi, dimana sangat berpengaruh sekali pada pembentukan jiwa anak. Motivasi belajar yang membangkitkan dan memberi arah pada dorongan yang menyebabkan individu melakukan perbuatan belajar (Silberman, 2004:ix).

\begin{tabular}{llr}
\multicolumn{2}{c}{ Guru dituntut untuk } \\
menguasai bermacam & inovasi \\
pembelajaran yang sesuai & dengan \\
karakteristik materi dan siswa. Dalam \\
memilih metode, kadar keaktifan \\
siswa harus selalu diupayakan tercipta \\
dan berjalan terus dengan \\
menggunakan beragam metode.
\end{tabular}
Keaktifan siswa di kelas sangat diperlukan karena proses kerja system memori sangat membantu perkembangan emosional siswa. Dalam Islam, penekanan proses kerja system memori terhadap signifikansi fungsi kognitif (aspek aqliah) dan fungsi sensori (indera-indera) sebagai alat-alat penting untuk belajar, sangat jelas. Dalam hal ini, system memori yang terdiri atas memori sensori, memori jangka pendek, dan memori jangka panjang berperan sangat aktif dan menentukan berhasil atau gagalnya seseorang dalam meraih pengetahuan dan keterampilan (Syah, 2004, hlm. 86).

Dalam Undang-undang No. 20 tahun 2003 tentang Sikdiknas Bab II Pasal 3 dijelaskan bahwa:
"Pendidikan Nasional
berfungsi mengembangkan
kemampuan
membentuk watak serta
peradaban bangsa yang
bermartabat dalam rangka
mencerdaskan kehidupan
bangsa, bertujuan untuk
berkembangnya potensi
peserta didik agar menjadi
manusia yang beriman dan
bertakwa kepada Tuhan
Yang Maha Esa, berahlak
mulia, sehat, berilmu,
cakap, kreatif, mandiri dan
menjadi warga negara yang
demokratis serta bertangguh
jawab."
Dengan proses belajar aktif, siswa akan mampu memecahkan masalahnya sendiri, yang paling penting melakukan tugasnya sesuai dengan pengetahuan yang mereka miliki. Persoalannya bagaimana mengaktifkan siswa agar secara sukarela tumbuh kesadaran mau dan senang belajar, guru harus mempunyai metode yang baik supaya pendidikan dan pembelajaran yang disampaikan memperoleh respon positif, menarik perhatian, dapat dikembangkan dan terimplementasi dalam sikap yang positif pula. Untuk mencapainya, seorang guru harus dapat memilih inovasi pembelajaran yang menarik karena metode yang biasa diterapkan monoton hanya terfokus pada materi saja.

Untuk meningkatkan mutu pembelajaran dalam kelas, banyak faktor yang harus dipertimbangkan diantaranya yaitu dalam hal penyampaian materi dari sumber 
melalui saluran atau media tertentu ke penerimaan siswa, sedangkan metode yang digunakan di sekolah dirasakan masih kurang menciptakan suasana kondusif dan siswa terkesan pasif. Hanya mendengarkan penjelasan guru tanpa ada respon dari siswa, sehingga yang diketahui siswa hanya tersimpan dalam memori saja, tidak diungkapkan. Penyebab dari kepasifan siswa di kelas yaitu takut salah atau tidak percaya diri dan siswa cenderung malu mengungkap pendapatnya.

Berdasarkan obervasi awal di SLB AKW Kumara Surabaya dan beberapa unit di dalamnya, masih ditemukan guru yang belum tepat dalam pemilihan dan penggunaan inovasi pembelajaran yang digunakan. Bila ditelusuri lebih lanjut, faktor yang meyebabkan guru belum mampu melaksanakan inovasi pembelajaran dengan tepat karena kinerja mengembangkan inovasi pembelajaran belum optimal, bahkan ada yang tidak membuat. Pengembangan inovasi pembelajaran sangat penting, karena perencanaan yang baik berpengaruh terhadap hasil belajar siswa (Observasi, 03 Oktober 2018).

Melihat kondisi seperti ini guru belum memiliki kompetensi dalam mengembangkan inovasi pembelajaran yang tepat. Sehubungan dengan hal tersebut maka Penelitian Tindakan Sekolah ini perlu dilaksanakan. Dengan keadaan demikian, peneliti sebagai pembina sekolah berusaha untuk memberi alternatif solusi, yaitu melalui kegiatan Team Teaching. Dalam hal ini, Team Teaching tampaknya bisa dijadikan sebagai alternatif untuk mengatasi permasalahan yang ada. Team Teaching merupakan salah satu bentuk metode yang melibatkan dua orang guru atau lebih dalam proses pembelajaran, dengan pembagian peran dan tanggung jawab secara jelas dan seimbang. Melalui Team Teaching, diharapkan antar mitra dapat bekerja sama dan saling melengkapi dalam mengelola proses pembelajaran. Setiap permasalahan yang muncul dalam proses pembelajaran dapat diatasi secara bersama-sama.

Berdasarkan latar belakang masalah di atas, maka peneliti tertarik untuk melakukan penelitian dengan menentukan judul Penerapan Supervisi Akademik sebagai Upaya Peningkatan Kompetensi Guru dalam Mengembangkan Inovasi Pembelajaran Melalui Kegiatan Team Teaching di SLB AKW Kumara Surabaya Tahun 2018.

Adapaun tujuan dari penelitian ini adalah: Mendeskripsikan Penerapan Supervisi Akademik sebagai Upaya Peningkatan Kompetensi Guru dalam Mengembangkan Inovasi Pembelajaran Melalui Kegiatan Team Teaching di SLB AKW Kumara Surabaya Tahun 2018.

\section{METODE}

Subyek dalam Penelitian Tindakan Sekolah ini adalah guruguru yang berasal dari SLB AKW Kumara Surabaya yang tergabung dalam kegiatan Team Teaching yang berjumlah 30 orang. Kegiatan ini bertempat di SLB AKW Kumara. 
Penelitian ini dilakukan dalam dua siklus dan masing-masing siklus terdiri atas: perencanaan, pelaksanaan, observasi dan refleksi. Refleksi adalah untuk menentukan keberhasilan suatu tindakan

Pada dasarnya siklus II memiliki prosedur yang sama dengan siklus I, hanya saja diadakan perbaikan pada hal-hal yang dilihat ada kelemahan serta mempertahankan hal-hal yang sudah berjalan dengan baik. Tidak menutup kemungkinan juga dilakukan modifikasi terhadap hal-hal sudah baik supaya tindakan yang diberikan tidak membosankan.

Teknik pengumpulan data dari penelitian tindakan sekolah ini adalah melalui wawancara, observasi, dan dokumentasi.

1. Wawancara. Teknik ini digunakan untuk mendapatkan data dari informan secara langsung. Dalam melakukan wawancara dipergunakan pedoman wawancara yang terbuka.

2. Observasi/Pengamatan.

Observasi digunakan untuk melengkapi data dari wawancara, terutama dalam lingkup masalah penelitian, antara lain: mengamati pengembangan inovasi pembelajaran melalui kegiatan Team Teaching.

3. Dokumentasi. Teknik ini digunakan untuk mengumpul data sekunder melalui dokumen-dokumen tertulis yang diyakini integritasnya karena mengambil dari berbagai sumber yang relevan dengan penelitian. Pengambilan sumber yang bersifat sekunder ini dapat diperoleh dari hasil dialog bersama kolaborator, data base sekolah, dan lain-lain.

Untuk mengalinasis kualitas pengembangan inovasi pembelajaran setelah mengikuti penelitian tindakan sekolah setiap putarannya dilakukan dengan cara memberikan evaluasi pada setiap akhir putaran. Analisis ini dihitung dengan menggunakan statistik sederhana, dengan rumus:

$$
\begin{aligned}
& \bar{X}=\frac{\sum X}{\sum N} \\
& \text { Dengan }: \bar{X}=\text { Nilai } \\
& \text { rata-rata } \\
& \Sigma \mathrm{X}=\text { Jumlah skor } \\
& \text { yang diperoleh } \\
& \Sigma \mathrm{N}=\text { Jumlah skor } \\
& \text { maksimal }
\end{aligned}
$$

\section{HASIL DAN PEMBAHASAN}

Masih banyak guru ditemukan kurang paham semua aspek yang ada dalam mengembangkan inovasi pembelajaran. Kesalahan umum yang tampak adalah: (1) guru belum mampu mengembangkan tujuan pembelajaran, (2) guru belum mampu menguraikan materi ajar dengan baik, (3) guru belum mampu menerapkan langkahlangkah pembelajaran sesuai inovasi pembelajaran yang direncanakan, (4) guru belum mampu membuat penilaian sesuai dengan metode yang digunakan, dan (5) guru belum mampu memanejemn waktu baik dalam kegiatan awal, inti dan penutup. Dengan kondisi awal seperti ini perlu adanya tindakan nyata yang 
Volume 3, No. 2 Januari 2020

diharapkan mampu meningkatkan kinerja guru dalam mengembangkan inovasi pembelajaran, yakni berupa Kegiatan Team Teaching.

\section{Siklus I}

Perencanaan terdiri atas: (1) melaporkan kegiatan penelitian kepada Kepala Cabang Dinas Pendidikan Jawa Timur Wilayah Kota Surabaya beserta mohon ijin penelitian, (2) berkoordinasi dengan beberapa Kepala Sekolah untuk menyampaikan ijin penelitian tersebut, dengan minta masukan tentang masalah yang ada sekaligus membicarakan tentang masalah teknis, waktu pelaksanaan penelitian dan hal-hal yang terkait dengan penelitian dan atau Kegiatan Team Teaching yang dilaksanakan, (3) bersama Kepala Sekolah memberikan pengarahan Kegiatan Team Teaching tentang inovasi pembelajaran, (4) mengelompokkan guru berdasarkan Mata Pelajaran, (5) menelaah konsep inovasi pembelajaran, mengkonsep inovasi pembelajaran yang mendekati kondisi mata pelajaran, (6) mendiskusikan konsep inovasi pembelajaran dan presentasi kelompok, (7) presentasi kelas, dan (8) menghasilkan inovasi pembelajaran final.

Di samping perencanaan umum, dilakukan juga perenanaan teknis pelaksanaan kegiatan seperti: (1) mengumpulkan guru melalui undangan kepala sekolah, (2) menyusun jadwal Kegiatan Team Teaching: hari, tanggal, jam dan tempat, (3) menyiapkan materi Kegiatan Team Teaching; pengarahan kepala sekolah, pemaparan materi inovasi pembelajaran dari ahli yang membidangi, (4) menyuruh guru membawa bahan-bahan seperti; kurikulum, silabus, RPP bahan ajar dan sebagainya, (5) pengelompokan guru menurut bidang studi, (6) menyiapkan konsumsi untuk kegiatan Kegiatan Team Teaching, dan (7) menyuruh guru membawa laptop.

Pada tahap pelaksanaan tindakan dilakukan beberapa langkah, yakni: (1) absensi peserta, (2) pengarahan kepala sekolah, (3) penjelasan umum kepada seluruh peserta, (3) peserta dikelompokan sesuai mata pelajaran, (4) guru mengkaji: standard kompetensi, kompetensi dasar (KD) sesuai model silabus rnata pelajaran masing-masing, materi pembelajaran, indikator, penilaian, (5) guru mengembangkan inovasi pembelajaran sesuai format yang telah disepakati yang berisi tentang aspek, materi dan kegiatan, dan (6) presentasi visual inovasi pembelajaran.

Selanjutnya yaitu dilakukan pengamatan terhadap pelaksanaan tindakan, yaitu menitikberatkan pada kompetensi guru dalam mengembangkan inovasi pembelajaran sebagai akibat diterapkan Kegiatan Team Teaching. Tujuan dilaksanakan pengamatan adalah untuk mengetahui kegiatan yang mana patut dipertahankan, diperbaiki, atau dihilangkan sehingga kegitan pembinaan melalui Kegiatan Team Teaching benar-benar berjalan sesuai dengan tujuan yang ada dan mampu meningkatkan kinerja peserta dalam mengembangkan inovasi pembelajaran.

Kegiatan peserta juga diobservasi, baik menyangkut 
kesiapan mental dan fisik guru, kesiapan bahan-bahan yang dibawa guru pada waktu Kegiatan Team Teaching, kehadiran guru, kesiapan laptop, kualitas inovasi pembelajaran, dan respon guru. Dari hasil pengamatan terhadap aktivitas peserta yang berjumlah 30 orang dengan menggunakan lembar observasi yang telah disiapkan, diperoleh data sebagai berikut.

Tabel 1. Hasil Observasi Tentang Kesiapan Guru dalam Mengikuti Kegiatan Team Teaching pada Siklus I

\begin{tabular}{|l|c|c|c|c|c|c|c|c|}
\hline & \multicolumn{9}{|c|}{ Aspek yang Diamati } \\
\cline { 2 - 10 } & $\begin{array}{c}\text { Kesiapan } \\
\text { mental dan } \\
\text { fisik guru }\end{array}$ & \multicolumn{2}{c|}{$\begin{array}{c}\text { Kesiapan } \\
\text { bahan }\end{array}$} & \multicolumn{2}{c|}{ Kehadiran Guru } & \multicolumn{2}{c|}{ Kesiapan Laptop } \\
\cline { 2 - 10 } & $\mathrm{S}$ & $\mathrm{TS}$ & $\mathrm{S}$ & $\mathrm{TS}$ & $\mathrm{H}$ & $\mathrm{TH}$ & $\mathrm{S}$ & $\mathrm{TS}$ \\
\hline Jumlah & 25 & 5 & 20 & 10 & 28 & 2 & 5 & 25 \\
\hline $\begin{array}{l}\text { Persentase } \\
(\%)\end{array}$ & 83.33 & 13.33 & 66.67 & 33.33 & 93.33 & 6.67 & 16.67 & 83.33 \\
\hline $\begin{array}{l}\text { Pencapaian } \\
\text { indiaktor } \\
\text { keberhasilan }\end{array}$ & Belum tercapai & \multicolumn{2}{|c|}{$\begin{array}{c}\text { Belum } \\
\text { tercapai }\end{array}$} & \multicolumn{2}{c|}{$\begin{array}{c}\text { Sudah } \\
\text { tercapai }\end{array}$} & $\begin{array}{c}\text { Belum } \\
\text { tercapai }\end{array}$ \\
\hline
\end{tabular}

Keterangan:

$$
\begin{array}{ll}
\mathrm{S} & =\text { siap } \\
\mathrm{TS} & =\text { tidak siap } \\
\mathrm{H} & =\text { hadir } \\
\mathrm{TH} & =\text { tidak hadir }
\end{array}
$$

Dari Tabel 1 di atas, tampak bahwa: pada aspek kesiapan mental dan fisik; 25 orang atau 85,33\% peserta siap dan 5 orang atau 13,33\% tergolong belum siap. Pada aspek kesipan bahan; tampak bahwa 20 orang guru atau $66,67 \%$ siap dan 10 orang atau 33,33\% belum siap. Pada aspek kehadiran guru tampak bahwa 28 orang atau $93,33 \%$ hadir dan 2 orang atau $6,67 \%$ tidak hadir. Pada aspek kesiapan laptop tampak bahwa 5 orang atau $16,67 \%$ siap dan 25 orang atau $83,33 \%$ belum siap. Berdasarkan dekripsi ini tampaknya kesiapan guru dalam mengikuti Kegiatan Team Teaching belum memenuhi kriteria keberhasilan untuk semua aspek.

Dari hasil evaluasi terhadap pengembangan inovasi pembelajaran yang dibuat oleh 30 orang guru setelah diadakan Kegiatan Team Teaching pada tahap awal (siklus I) diperoleh kinerja guru mengembangkan inovasi pembelajaran seperti tampak pada Tabel 2 berikut. 
Volume 3, No. 2 Januari 2020

Tabel 2. Hasil Penilaian Komptensi Guru dalam Mengembangkan Inovasi Pembelajaran pada Siklus I

\begin{tabular}{|c|c|c|c|c|c|c|c|c|c|}
\hline \multirow{3}{*}{$\begin{array}{l}\mathbf{N} \\
\mathbf{o}\end{array}$} & \multirow{3}{*}{$\begin{array}{l}\text { Aspek yang } \\
\text { Dinilai }\end{array}$} & \multicolumn{8}{|c|}{ Skor } \\
\hline & & \multicolumn{2}{|c|}{1} & \multicolumn{2}{|c|}{2} & \multicolumn{2}{|c|}{3} & \multicolumn{2}{|c|}{4} \\
\hline & & $\mathrm{Jml}$ & $\%$ & $\mathrm{Jml}$ & $\%$ & $\mathrm{Jml}$ & $\%$ & $\mathrm{Jml}$ & $\%$ \\
\hline 1. & $\begin{array}{l}\text { Inovasi } \\
\text { Perencanaan } \\
\text { Pembelajaran }\end{array}$ & 5 & $\begin{array}{c}16,6 \\
7\end{array}$ & 5 & 16,67 & 10 & $\begin{array}{c}33,3 \\
3\end{array}$ & 10 & $\begin{array}{c}33,3 \\
3\end{array}$ \\
\hline 2. & $\begin{array}{l}\text { Inovasi Materi } \\
\text { Pembelajaran }\end{array}$ & 2 & 6,67 & 7 & 23,33 & 10 & $\begin{array}{c}33,3 \\
3\end{array}$ & 11 & $\begin{array}{c}36,6 \\
7\end{array}$ \\
\hline 3. & $\begin{array}{l}\text { Inovasi } \\
\text { Metode } \\
\text { Pembelajaran }\end{array}$ & 3 & $\begin{array}{c}10,0 \\
0\end{array}$ & 6 & 20,00 & 10 & $\begin{array}{c}33,3 \\
3\end{array}$ & 11 & $\begin{array}{c}36,6 \\
7\end{array}$ \\
\hline 4. & $\begin{array}{l}\text { Inovasi Media } \\
\text { Pembelajaran }\end{array}$ & 2 & 6,67 & 5 & 16,67 & 12 & $\begin{array}{c}40,0 \\
0\end{array}$ & 11 & $\begin{array}{c}36,6 \\
7\end{array}$ \\
\hline 5. & $\begin{array}{l}\text { Inovasi } \\
\text { Evaluasi } \\
\text { Pembelajaran }\end{array}$ & 1 & 3,33 & 8 & 26,67 & 10 & $\begin{array}{c}33,3 \\
3\end{array}$ & 11 & $\begin{array}{c}36,6 \\
7\end{array}$ \\
\hline
\end{tabular}

Keterangan:

$4=$ sangat baik $\quad 2=$ cukup

$3=$ baik $\quad 1=$ tidak baik

Dari Tabel 2 di atas, pada aspek Inovasi Perencanaan Pembelajaran; 5 orang atau $16,67 \%$ guru dalam kategori tidak baik, 5 orang atau 16,67 tergolong cukup, 10 orang atau $33,33 \%$ tergolong baik dan 10 orang atau 33,33\% tergolong sangat baik. Bila dijumlahkan antara yang berkategori baik dan sangat baik mencapai 20 orang atau $66,67 \%$.

Pada aspek Inovasi Materi Pembelajaran, tampak bahwa 2 orang atau $6,67 \%$ tergolong tidak baik, 7 orang atau $23,33 \%$ tergolong cukup, 10 orang atau $33,33 \%$ tergolong baik dan 11 orang atau 36,67\% tergolong sangat baik. Bila dijumlahkan antara yang baik dan sangat baik mencapai 21 orang atau $70,00 \%$.
Pada aspek Inovasi Metode Pembelajaran; 3 orang atau 10,00\% guru dalam kategori tidak baik, 6 orang atau $20,00 \%$ tergolong cukup, 10 orang atau $33,33 \%$ tergolong baik dan 11 orang atau 33,67\% tergolong sangat baik. Bila dijumlahkan antara yang berkategori baik dan sangat baik mencapai 21 orang atau $70 \%$.

Pada aspek Inovasi Media Pembelajaran; 2 orang atau $6,67 \%$ guru dalam kategori tidak baik, 5 orang atau 16,67\% tergolong cukup, 12 orang atau $40,00 \%$ tergolong baik dan 11 orang atau 33,67\% tergolong sangat baik. Bila dijumlahkan antara yang berkategori baik dan sangat baik mencapai 23 orang atau 76,67\%.

Pada aspek Inovasi Evaluasi Pembelajaran; 1 orang atau 3,33\% guru dalam kategori tidak baik, 8 
orang atau $26,67 \%$ tergolong cukup, 10 orang atau $33,33 \%$ tergolong baik dan 11 orang atau $33,67 \%$ tergolong sangat baik. Bila dijumlahkan antara yang berkategori baik dan sangat baik mencapai 21 orang atau $70,00 \%$.

Berdasarkan dekripsi pada tabel 1 dan 2 tampaknya kompetensi guru dalam mengembangkan inovasi pembelajaran, para guru belum memenuhi indikator kinerja yang telah ditetapkan pada semua aspek, baik kesiapan maupun kinerja mengembangkan inovasi pembelajaran.

Hasil refleksi yang diperoleh menunjukkan kinerja guru dalam mengembangkan inovasi pembelajaran pada siklus I belum menunjukkan hasil sesuai dengan indikator yang telah ditetapkan. Setelah diadakan refleksi terhadap hasil yang diperoleh, diputuskan untuk memperbaiki dari segi kegiatan Kegiatan Team Teaching terutama memperjelas tentang aspek yang belum sesuai dengan indikator kinerja yang telah ditetapkan.

Dari masalah tersebut, diputuskan untuk memperbaiki beberapa langkah dalam siklus I, yakni memfokuskan pada penjelasan tentang pengembangan aspek métode dan media pembelajaran dalam kaitannya dengan mengembangkan inovasi pembelajaran. Langkah-langkah ini dijalankan pada siklus II dengan tetap mempertahankan kegiatan yang lain yang sudah dianggap baik. Untuk meningkatkan kesiapan guru, fasilitator memberikan kesadaran bahwa petapa penting perencanaan pembelajaran yang dibuat guru sebelum melaksanakan pembelajaran. Mengenai altrnatif untuk menambah laptop diputuskan untuk memanfaatkan IT yang ada di sekolah sehingga semua guru mendapatkan kesempatan satu per satu.

\section{Siklus II}

Pada siklus II, langkah-langkah yang diambil sesuai dengan refleksi hasil siklus I mengikuti langlahlangkah seperti siklus I dengan memfokuskan pada penjelasan aspekaspek yang belum dipahami guru dalam mengembangkan inovasi pembelajaran lebih menitikberatkan pada aspek pembimbingan secara individu. Dari 30 orang guru semua dilibatkan dalam siklus II untuk memperdalam pengetahuan tentang pengembangan inovasi pembelajaran. Setelah siklus II dijalankan yang mengacu pada refleksi dan pemecahan masalah pada sikuls I diperoleh data tentang seperti tampak pada Tabel 3 berikut. 
Volume 3, No. 2 Januari 2020

Tabel 3. Hasil Observasi Tentang Kesiapan Guru dalam Mengikuti Kegiatan Team Teaching pada Siklus II

\begin{tabular}{|c|c|c|c|c|c|c|c|c|}
\hline & \multicolumn{8}{|c|}{ Aspek yang Diamati } \\
\hline & \multicolumn{2}{|c|}{$\begin{array}{l}\text { Kesiapan } \\
\text { Mental dan } \\
\text { Fisik Guru }\end{array}$} & \multicolumn{2}{|c|}{$\begin{array}{c}\text { Kesiapan } \\
\text { Bahan }\end{array}$} & \multicolumn{2}{|c|}{$\begin{array}{l}\text { Kehadiran } \\
\text { Guru }\end{array}$} & \multicolumn{2}{|c|}{$\begin{array}{l}\text { Kesiapan } \\
\text { Laptop }\end{array}$} \\
\hline & $\mathrm{S}$ & $\mathrm{TS}$ & $\mathrm{S}$ & TS & $\mathrm{H}$ & $\mathrm{TH}$ & $\mathrm{S}$ & $\mathrm{TS}$ \\
\hline Jumlah & 28 & 2 & 27 & 3 & 30 & 0 & 20 & 10 \\
\hline Persentase (\%) & $\begin{array}{c}93,3 \\
3\end{array}$ & 6,67 & 90,00 & 10,00 & 100 & 0,00 & $\begin{array}{c}66,6 \\
7\end{array}$ & 33,33 \\
\hline $\begin{array}{l}\text { Pencapaian } \\
\text { indiaktor } \\
\text { keberhasilan }\end{array}$ & \multicolumn{2}{|c|}{ Tercapai } & \multicolumn{2}{|c|}{ Tercapai } & \multicolumn{2}{|c|}{ Tercapai } & \multicolumn{2}{|c|}{ Tercapai } \\
\hline
\end{tabular}

Keterangan:

$$
\begin{array}{ll}
\mathrm{S} & =\text { siap } \\
\mathrm{TS} & =\text { tidak siap } \\
\mathrm{H} & =\text { hadir } \\
\mathrm{TH} & =\text { tidak hadir }
\end{array}
$$

Dari Tabel 3 di atas, tampak bahwa: pada aspek kesiapan mental dan fisik; 28 orang atau 93,33\% peserta siap dan 2 orang atau 6,67\% tergolong belum siap. Pada aspek kesiapan bahan; tampak bahwa 27 orang guru atau $90,00 \%$ siap dan 3 orang atau $10,00 \%$ belum siap. Pada aspek kehadiran guru tampak bahwa 30 orang atau $100 \%$ hadir dan tidak ada orang atau $0,00 \%$ tidak hadir. Pada aspek kesiapan laptop tampak bahwa 20 orang atau $66,67 \%$ siap dan
10 orang atau $33,33 \%$ belum siap. Berdasarkan dekripsi ini tampaknya kesiapan guru dalam mengikuti Kegiatan Team Teaching belum telah memenuhi kriteria keberhasilan untuk semua aspek. Namun belum sepenuhnya tercapai seratus persen.

Dari hasil evaluasi terhadap pengembangan inovasi pembelajaran yang dibuat oleh 30 orang guru setelah diadakan kegiatan Team Teaching pada siklus II diperoleh kinerja guru mengembangkan inovasi pembelajaran seperti tampak pada Tabel 4 berikut.

Tabel 4. Hasil Penilaian Komptensi Guru dalam Mengembangkan Inovasi Pembelajaran Pada Siklus II

\begin{tabular}{|c|l|c|c|c|c|c|c|c|c|}
\hline \multirow{2}{*}{$\begin{array}{c}\text { N } \\
\mathbf{0}\end{array}$} & \multirow{2}{*}{$\begin{array}{c}\text { Aspek yang } \\
\text { Dinilai }\end{array}$} & \multicolumn{9}{|c|}{ Skor } \\
\cline { 2 - 10 } & \multicolumn{2}{|c|}{1} & \multicolumn{2}{|c|}{2} & \multicolumn{2}{|c|}{3} & \multicolumn{2}{|c|}{4} \\
\hline 1. & $\begin{array}{l}\text { Inovasi } \\
\text { Perencanaan } \\
\text { Pembelajaran }\end{array}$ & 0 & 0,00 & 1 & 3,33 & 14 & 46,67 & 15 & $\begin{array}{c}50,0 \\
0\end{array}$ \\
\hline 2. & $\begin{array}{l}\text { Inovasi Materi } \\
\text { Pembelajaran }\end{array}$ & 0 & 0,00 & 2 & 6,67 & 12 & 40,00 & 16 & $\begin{array}{c}53,3 \\
3\end{array}$ \\
\hline 3. & $\begin{array}{l}\text { Inovasi Metode } \\
\text { Pembelajaran }\end{array}$ & 1 & 3,33 & 2 & 6,67 & 13 & 43,33 & 14 & $\begin{array}{c}46,6 \\
7\end{array}$ \\
\hline 4. & Inovasi Media & 0 & 0,00 & 1 & 3,33 & 14 & 46,67 & 15 & 50,0 \\
\hline
\end{tabular}


Volume 3, No. 2 Januari 2020

\begin{tabular}{|c|l|c|c|c|c|c|c|c|c|}
\hline & Pembelajaran & & & & & & & & 0 \\
\hline 5. & $\begin{array}{l}\text { Inovasi } \\
\text { Evaluasi } \\
\text { Pembelajaran }\end{array}$ & 0 & 0,00 & 1 & 3,33 & 13 & 43,33 & 16 & $\begin{array}{c}53,3 \\
3\end{array}$ \\
\hline
\end{tabular}

Keterangan:

$4=$ sangat baik $\quad 2=$ cukup

3 = baik $\quad 1=$ tidak baik

Dari Tabel 4 di atas, pada aspek Inovasi Perencanaan Pembelajaran; tidak ada orang atau $0,00 \%$ guru dalam kategori tidak baik, 1 orang atau $3,33 \%$ tergolong cukup, 14 orang atau $46,67 \%$ tergolong baik dan 15 orang atau $50,00 \%$ tergolong sangat baik. Bila dijumlahkan antara yang berkategori baik dan sangat baik mencapai 29 orang atau 96,67\%.

Pada aspek Inovasi Materi Pembelajaran, tampak bahwa 0 orang atau $0,00 \%$ tergolong tidak baik, 2 orang atau $6,67 \%$ tergolong cukup, 12 orang atau $40,00 \%$ tergolong baik dan 16 orang atau $53,33 \%$ tergolong sangat baik. Bila dijumlahkan antara yang baik dan sangat baik mencapai 28 orang atau $93,33 \%$.

Pada aspek Inovasi Metode Pembelajaran; 1 orang atau 3,33\% guru dalam kategori tidak baik, 2 orang atau $6,67 \%$ tergolong cukup, 13 orang atau $43,33 \%$ tergolong baik dan 14 orang atau $46,67 \%$ tergolong sangat baik. Bila dijumlahkan antara yang berkategori baik dan sangat baik mencapai 27 orang atau 90,00\%.

Pada aspek Inovasi Media Pembelajaran; tidak ada orang atau $0,00 \%$ guru dalam kategori tidak baik, 1 orang atau $3,33 \%$ tergolong cukup, 14 orang atau $46,67 \%$ tergolong baik dan 15 orang atau 50,00\% tergolong sangat baik. Bila dijumlahkan antara

yang berkategori baik dan sangat baik mencapai 29 orang atau 96,67\%.

Pada aspek Inovasi Evaluasi Pembelajaran; tidak ada orang atau $0,00 \%$ guru dalam kategori tidak baik, 1 orang atau 3,33\% tergolong cukup, 13 orang atau $43,33 \%$ tergolong baik dan 16 orang atau 53,33\% tergolong sangat baik. Bila dijumlahkan antara yang berkategori baik dan sangat baik mencapai 29 orang atau 96,67\%.

Berdasarkan dekripsi pada tabel 3 dan 4 tampaknya kompetensi guru mengembangkan inovasi pembelajaran para guru sudah memenuhi indikator yang telah ditetapkan pada semua aspek, baik menyangkut kesiapan maupun kinerja mengembangkan inovasi pembelajaran. Dengan hasil seperti itu, berarti tindakan yang diberikan efektif dalam meningkatkan kinerja guru dalam mengembangkan inovasi pembelajaran.

Berdasarkan analisis dan pembahasan seperti yang telah dipaparkan pada bagian sebelumnya, maka dapat disimpulkan bahwa terjadi peningkatan aktivitas peserta dalam kegiatan Team Teaching tentang pengembangan inovasi pembelajaran bagi guru-guru di SLB AKW Kumara Surabaya. Di samping itu juga, terjadi peningkatan kompetensi guru dalam mengembangkan inovasi pembelajaran melalui kegiatan Team Teaching dari siklus I ke siklus II pada masingmasing aspek dengan target 
ketercapaian sesuai dengan kriteria yang ditetapkan. Dengan demikian dapat disimpulkan bahwa melalui kegiatan Team Teaching dapat meningkatkan kompetensi guru dalam mengembangkan inovasi pembelajaran guru, khususnya di SLB AKW Kumara Surabaya.

Keberhasilan tindakan ini disebabkan oleh pemahaman secara menyeluruh tentang inovasi pembelajaran sangat diperlukan. Dengan pemahaman yang baik, maka inovasi pembelajaran dapat disusun dengan baik. Mengoptimalkan pemahaman guru terhadap inovasi pembelajaran melalui pembinaan intensif dalam bentuk penyelenggaraan kegiatan Team Teaching menunjuk pada metode kooperatif konsultatif dimana diharapkan para guru berdiskusi, bekerja sama dan berkonsultasi secara aktif. Aktivitas ini akan sangat membantu mereka dalam memahami konsep-konsep dasar pengembangan inovasi pembelajaran serta pada akhirnya nanti mereka mampu mengembangkan inovasi pembelajaran dengan baik dan benar.

Dalam kaitannya dengan pembinaan melalui kegiatan Team Teaching, maka penelitian ini juga sesuai dengan apa yang dikatakan Amstrong (1990, hlm. 209) bahwa tujuan kegiatan Team Teaching adalah untuk memperoleh tingkat kinerja yang diperlukan dalam pekerjaan mereka dengan cepat dan ekonomis dan mengembangkan kinerja-kinerja yang ada sehingga prestasi mereka pada tugas yang sekarang ditingkatkan dan mereka dipersiapkan untuk menerima tanggung jawab yang lebih besar di masa yang akan datang. Siswanto (1989, hlm. 139) mengatakan kegiatan Team Teaching bertujuan untuk memperoleh nilai tambah seseorang yang bersangkutan, terutama yang berhubungan dengan meningkatnya dan berkembangnya pengetahuan, sikap, dan keterampilan yang bersangkutan. kegiatan Team Teaching dimaksudkan untuk mempertinggi kinerja dengan mengembangkan cara-cara berpikir dan bertindak yang tepat serta pengetahuan tentang tugas pekerjaan termasuk tugas dalam melaksanakan evaluasi diri (As'ad, 1987, hlm. 64).

Dari paparan di atas, menunjukkan bahwa peningkatan kompetensi guru dalam mengembangkan inovasi pembelajaran melalui kegiatan Team Teaching yang lebih menekankan pada metode kolaboratif konsultatif akan memberikan kesempatan sharing antara satu guru dengan guru lain. Dengan demikian, pemahaman terhadap inovasi pembelajaran dapat ditingkatkan baik dalam teoretisnya maupun implementasinya.

\section{PENUTUP Simpulan}

Berdasarkan hasil analisis data, dari penelitian ini dapat ditarik suatu kesimpulan bahwa: terjadi peningkatan kesiapan peserta dalam kegiatan Team Teaching di SLB AKW Kumara Surabaya. Di samping itu juga, terjadi peningkatan kompetensi guru dalam mengembangkan inovasi pembelajaran melalui pembinaan 
berupa Team Teaching dari siklus I ke siklus II dan mencapai target minimal yang telah ditetapkan yakni $85 \%$, artinya $85 \%$ guru telah efektif dalam mengembangkan inovasi pembelajaran pada masing-masing aspek.

Selain itu, terjadi peningkatan kompetensi guru dalam mengembangkan inovasi pembelajaran melalui Team Teaching. Hal itu terbukti bahwa siklus I ke siklus II, kategori baik dan sangat baik pada aspek Inovasi Perencanaan Pembelajaran meningkat dari 66,67\% menjadi 96,67\%. Pada aspek Inovasi Materi Pembelajaran meningkat dari 70,00\% menjadi 93,33\%. Pada aspek Inovasi Metode Pembelajaran meningkat dari $70,00 \%$ menjadi 90,00\%. Pada aspek Inovasi Media Pembelajaran meningkat dari 76,67\% menjadi 96,67\%. Pada aspek Inovasi Evaluasi Pembelajaran meningkat dari $70,00 \%$ menjadi $96,67 \%$.

\section{Saran}

Berdasarkan hasil penelitian yang diperoleh, dapat disarakan beberapa hal, antara lain: (1) para guru sebaiknya mengembangkan inovasi pembelajaran berdasarkan kebutuhan siswa dan memperhatikan proporsi waktu yang ada dan tidak hanya mencontoh inovasi pembelajaran yang telah ada, (2) agar pembinaan melalui kegiatan Team Teaching dapat berjalan secara efektif, maka semua guru harus mampu bekerjasama dengan peserta lain yang bersifat kolaboratif konsultatif.

\section{DAFTAR PUSTAKA}

Ahmadi, A. dan Prasetya. (2005). Strategi Belajar Mengajar. Bandung: CV Pustaka Setia

Anonim. (2008). Petunjuk Teknis Penelitian tindakan Sekolah (School Action Research) Peningkatan Kompetensi Supepervisi Pengawas sekolah. Jakarta : Departemen Pendidikan Nasional Derektorat Jendral PMPTK

Arief, Armai. (2002). Pengantar Ilmu dan Metodologi Pendidikan Islam. Ciputat: Ciputat Press

Cerbin, Bill \& Bryan Kopp. (2010). A Brief Introduction to College Kegiatan Team Teaching. Kegiatan Team Teaching Project. Dalam http ://www.uwlax.edu/sotl/lsp/.htm

Departemen Pendidikan dan Kebudayaan. (1995). Kamus Besar Bahasa Indonesia. Jakarta: Balai Pustaka

Friedenberg, Lisa. (1995). Psychological Testing: Design, Analysus, and Use. Boston: Allyn and Bacon

Kemendiknas. (2003). Standar Kompetensi Guru Sekolah Dasar. Jakarta: Direktorat Jenderal Pendidikan Dasar dan Menengah Direktorat Tenaga Kependidikan

Kemendiknas. (2007). Pedoman Bantuan Langsung (Block Grant) Pelaksanaan Penelitian Tidakan bagi Pengawas Sekolah. Jakarta: Direktoral Tenaga Kependidikan Direktoral Jendral 
Volume 3, No. 2 Januari 2020

Peningkatan Mutu Pendidikan

Simamora, Henry. (1995). dsar dan menengah Direktorat Tenaga Kependidikan

Manajemen Sumber Daya Manusia. Yogyakarta: STIE YPKN.

Rasyid, Mahmunar. (2005). Inovasi Pembelajaran Sejarah Melalui Pendekatan Team Games Tournament dengan Sistem Porlimawih. Jakarta: Depdiknas

Silberman, M Melvin. (2004). Active Learning (101 Strategies to Teach Any Subject. Bandung: Nusa Media

Suryosubroto. (1997). Proses Pembelajaran di Sekolah. Jakarta: Rineka Cipta

Syah, Muhibbin. (2004). Psikologi Pendidikan, Bandung: Rosdakarya 